\title{
Congress and Bush set to clash on stem cells again
}

In a direct but possibly futile challenge to the only veto of George Bush's presidency, the US Congress is expected to pass a bill for a second time that would dramatically expand researchers' access to human embryonic stem-cell lines. As Nature went to press, a vote in the House of Representatives was expected on 11 January, with the Senate likely to act on an identical measure within a few weeks.

The bill would allow federal funds to be used for research on stem-cell lines derived from surplus embryos at fertility clinics and otherwise slated for destruction. The embryos would have to be donated with informed consent and without payment or other inducements.

The California-based Rand Corporation estimated in 2003 that about 11,000 of the roughly 400,000 embryos stored at US fertility clinics at that time were available for research, from which it should be possible to derive up to 275 cell lines (D. I. Hoffman et al. Fertil. Steril. 79, 1063-1069; 2003). The study's lead author, David Hoffman of IVF Florida Reproductive Associates in Margate, estimates that there may now be $10-15 \%$ more embryos in storage. Under current Bush administration policy, only around 20 stem-cell lines, all created before 9 August 2001, are available to federally funded researchers. These ageing lines are contaminated by having been grown on 'feeder' layers of mouse cells, making them impractical for developing human therapies.

Bush vetoed an identical bill last summer after both the House and Senate passed it, and the House failed by 51 votes to muster the twothirds majority needed to override his veto (see Nature 442, 335; 2006). Bush is likely to veto the bill again, and even with Democratic election gains in November, it is doubtful whether stem-cell supporters in the House have the votes to override Bush. Just 13 of the House members who voted with Bush last summer were defeated in November. And seven of the newly elected Democrats are anti-abortion.

But in the Senate, which passed the bill by 63 to 37 last summer, November's elections ushered in a net gain of three senators who are likely to approve of the measure, bringing supporters within one vote of a veto-proof majority. If the Senate did override a second Bush veto, pressure on House members to do the same could substantially increase.

The Democrats, newly in charge of the House and Senate, have made it an early priority to reintroduce the bill, now dubbed the Stem Cell Research Enhancement Act of 2007. "There is growing support for ethical embry-

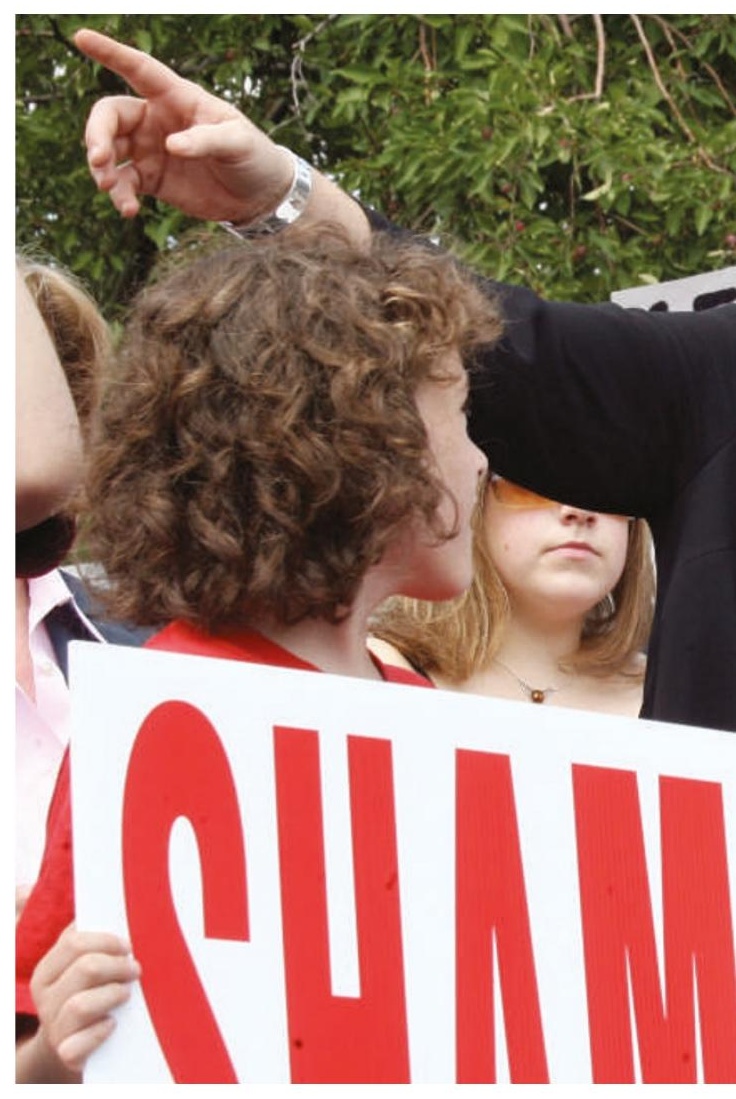

Diana DeGette sees a public consensus in favour of federal funding of embryonic stem-cell research.

onic stem-cell research in Congress, which is caused by a solid public consensus supporting this research," Representative Diana DeGette (Democrat, Colorado), one of the bill's two House authors, told Nature shortly before she introduced the bill on 5 January.

Opponents such as Senator Sam Brown-

\section{Indian science is in decline, says prime minister}

\section{BANGALORE}

For several years, criticisms have been aired at India's scientific meetings and in its journals. Now the country's top politician has spoken out about the talent crisis and poor standards affecting Indian science.

Prime Minister Manmohan Singh voiced his feelings on 3 January, when he opened the 94th Indian Science Congress (ISC) in Chidambaram in southern India. The annual meeting attracts thousands of scientists from across the country. Traditionally opened by the prime minister, it is generally an occasion to praise Indian science. But this year was different.

"While our government will do its utmost to invest in science, I call upon the scientific community to also invest its time and intellectual energy in the revitalization of our science institutions," said Singh. He added that he is "deeply concerned" about declining enrolment in basic sciences, and said that the decaying university system "needs upgrading in a massive way".

Singh was most troubled, he said, by "the decline in the standards of our research work in universities and even in advanced research institutes". For example, the return on billions of rupees invested in alternative energy sources was inadequate. "Be it [hydropower], thermal or nuclear power, we have to improve the productivity of investments already made." To raise quality, Singh warned that he may submit India's research labs to international peer review.

This is the first time that Singh has publicly criticized Indian science. His comments were apparently provoked by briefings from his science adviser, the distinguished chemist C. N. R. Rao, indicating that India publishes only $2.7 \%$ of the world's science papers (compared with China's 6\%) and describing the flight of talent 
